\title{
ODPOWIEDZIALNE PRZEDSIĘBIORSTWO W ODPOWIEDZIALNYM OTOCZENIU
}

\section{WSTĘP}

W ciągu ostatnich lat dyskusja na temat społecznej odpowiedzialności przedsiębiorstw (SOP, ang. Corporate Social Responsibility, CSR) cieszy się dużym zainteresowaniem zarówno wśród środowisk naukowych, jak i w świecie gospodarczym. Dzięki aktywności przedsiębiorstw w tym obszarze i licznym akcjom komunikacyjnym zagadnienie SOP wkracza coraz silniej również w życie codzienne. $Z$ drugiej strony, nasuwa się refleksja na temat tego czym właściwie jest SOP i jaką odgrywa ona rolę w rozwoju społeczeństwa.

Koncepcja społecznej odpowiedzialności zakłada długofalowy charakter działań podmiotów gospodarczych, bazując na przekonaniu o zgodności interesów społecznych $\mathrm{z}$ biznesowymi. W jaki sposób jednak mają postępować organizacje, jeżeli oczekiwania i zachowania ich społecznego otoczenia nie zachęcają do prowadzenia działań w sposób odpowiedzialny, szczególnie $\mathrm{w}$ obszarach istotnych $\mathrm{z}$ perspektywy długofalowej? Celem artykułu jest analiza relacji między przedsiębiorstwem społecznie odpowiedzialnym a wybranymi grupami interesu. W szczególności rozważane są kwestie postaw i zachowań konsumentów i pracowników, które mogą przyczynić się do wzrostu znaczenia wartości społecznej odpowiedzialności w otoczeniu organizacji, przyczyniając się tym samym do kształtowania instytucjonalnych ram sprzyjających rozwojowi społecznej odpowiedzialności przedsiębiorstw.

\section{JAK OTOCZENIE KSZTAŁTUJE CHARAKTER SPOŁECZNEJ ODPOWIEDZIALNOŚCI PRZEDSIĘBIORSTW?}

Społeczna odpowiedzialność przedsiębiorstw jest konstruktem trudnym do jednoznacznego zdefiniowania, przede wszystkim ze względu na wielość moż- 
liwych perspektyw rozpatrywania problemu. Zagadnienie to można analizować z punktu widzenia ekonomicznego, etycznego, a także pod względem interesu własnego przedsiębiorstwa, czy ogólnie pojętego interesu społecznego ${ }^{1}$. Wszystkie wymienione stanowiska tworzą odmienne perspektywy dla analizy tej koncepcji, jednak koncentrując się na zachowaniach i powinnościach samego przedsiębiorstwa, często pomijają wpływ, jaki ma otoczenie na charakter jego działań. Szeroka analiza jest możliwa w ujęciu instytucjonalnym, w którym podkreśla się znaczenie instytucji, czyli struktur o charakterze poznawczym, normatywnym i regulacyjnym, które ugruntowują i nadają znaczenie zachowaniom społecznym ${ }^{2}$. W podejściu tym zakłada się, że otoczenie zewnętrzne sprawuje kontrolę nad zasobami istotnymi dla organizacji, co prowadzi do tworzenia się pewnego rodzaju presji. Przedsiębiorstwa, chcąc uzyskać legitymizację społeczeństwa szukają czynników kluczowych dla uzyskania akceptacji swoich działań w środowisku poprzez analizę otoczenia. Analiza otoczenia zewnętrznego obejmuje czynniki charakterystyczne dla danej gospodarki, tj.: aspekty kulturowe (wartości, normy, zwyczaje), prawne (system polityczno-prawny), ekonomiczne (system finansowy, czynniki mikro- i makroekonomiczne) oraz system edukacji i stosunki pracy. ${ }^{3} \mathrm{~W}$ modelu wyjaśniającym powstawanie różnic w kształtowaniu społecznej odpowiedzialności w odmiennych warunkach kulturowych, badacze Dirk Matten i Jeremy Moon wskazują na wpływ szeregu procesów instytucjonalnych, a w szczególności na wyróżnione przez DiMaggio i Powella, trzy główne formy nacisku, jakie otoczenie instytucjonalne może wywierać na organizacje. Są to ${ }^{4}$ :

1) przymusowe dopasowanie (ang. coercive isomorphisms), polegające na wprowadzaniu wymogów prawnych dotyczących sprawozdawczości oraz dostosowywaniu się do obowiązujących norm;

2) procesy naśladowania (ang. mimetic processes), przejawiające się m.in. w koncepcjach benchmarkingu, uczenia się od najlepszych oraz promowaniu wzorcowych praktyk;

3) naciski normatywne (ang. normative pressures), które objawiać się mogą poprzez wpływ autorytetów na kształtowanie opinii w zakresie legitymizacji działań przedsiębiorstw.

7 K. Basu, G. Palazzo, Corporate Social Responsibility: a process model of sensemaking, „Academy of Management Review" 2008, vol. 33, no. 1, s. 121-122.

${ }^{8}$ R. W. Scott, Institions and Organization, Thousand Oaks, Sage 2001.

9 D. Matten, J. Moon, "Implicit" and "Explicit" CSR: a conceptual framework for a comparative understanding of Corporate Social Responsibility, „Academy of Management Review” 2008, vol. 33 , no. 2 , s. 413 .

${ }^{10}$ P. J. Di Maggio, W. W. Powell, The iron cage revisited: Institutional isomorphism and collective rationality in organizational fields, „American Sociological Review” 1983, no. 48, s. 48. 
Matten i Moon wskazują również na wpływ ogólnych ram instytucjonalnych, jak system polityczny, finansowy, edukacyjny, natura firmy, organizacja procesów rynkowych oraz funkcjonowanie systemów koordynacji i kontroli w poszczególnych regionach. Te z kolei, oddziałując na organizację, determinują charakter jej społecznej odpowiedzialności, która może być wyrażona explicit, jako część polityki przedsiębiorstwa lub implicit, jako zintegrowana część jego systemu ${ }^{5}$. Takie rozróżnienie wskazuje na to, że SOP - w zależności od warunków, w jakich funkcjonuje przedsiębiorstwo - może być elementem bazującym na wartościach zakorzenionych w systemie społeczno-gospodarczym lub może stanowić odpowiedź na oczekiwania otoczenia i wyrażać się w strategii i inicjatywach, podejmowanych przez firmy na rzecz społecznego otoczenia.

W wyżej przedstawionym modelu omówiono czynniki i procesy zewnętrzne, mające wpływ na kształtowanie i postrzeganie przedsiębiorstwa w społeczeństwie, a także charakter jego społecznej odpowiedzialności. Jednak, dla uzyskania pełniejszego obrazu istoty SOP, nie wystarczy wskazanie czynników zewnętrznych, które mają wpływ na kształtowanie koncepcji - należy również „zajrzeć” do środka organizacji i postarać się zrozumieć, czym jest społeczna odpowiedzialność dla jej członków. Badacze Kunal Basu i Guido Palazzo, w takim ujęciu, definiują SOP jako proces według którego menedżerowie rozważają relacje organizacji $z$ interesariuszami, i rozumieją swoją rolę w odniesieniu do tworzenia wspólnego dobra, mając na względzie osiągnięcie celów w obszarze kształtowania tych relacji ${ }^{6}$. W modelu systematyzującym czynniki wewnętrzne, determinujące charakter społecznej odpowiedzialności w przedsiębiorstwie autorzy wyróżniają trzy płaszczyzny. Na pierwszej płaszczyźnie - o charakterze poznawczym - wskazują dwa istotne aspekty: rodzaj tożsamości organizacyjnej oraz sposób, w jaki przedsiębiorstwo stara się o legitymizację swoich działań. Tożsamość organizacyjna może mieć charakter indywidualistyczny, kiedy pracownik postrzegany jest jako jednostka, która wiąże się z organizacją na zasadach transakcyjnego kontraktu psychologicznego, dla którego podstawową wartością jest umowa. Tożsamość organizacyjna może mieć również charakter relacyjny, w którym najważniejszymi wartościami są relacje pomiędzy uczestnikami organizacji oraz kolektywistyczny, gdzie podstawową wartością jest realizacja wspólnego celu. Legitymizacja działań może natomiast mieć charakter pragmatyczny, odnoszący się do użyteczności działań; poznawczy, który bazuje na rozpoznaniu relacji i zrozumieniu potrzeb otoczenia i odpowiedzi na nie, oraz moralny, gdzie podkreśla

11 D. Matten, J. Moon, op. cit., s. 413.

12 K. Basu, G. Palazzo, op. cit. s. 124. 
się powiązanie podejmowanych działań z dążeniem do wybranego celu, który ma uzasadnienie moralne. Na drugiej płaszczyźnie analizuje się to, „co firmy mówią" (płaszczyzna lingwistyczna) - istotny jest tu sposób, w jaki przedsiębiorstwa uzasadniają swoje działania (argumenty o charakterze prawnym, naukowym, ekonomicznym lub etycznym) oraz stosunek organizacji do zachowania przejrzystości działań (komunikowanie zbilansowane, uwzględniające całe spektrum działań lub spolaryzowane, skoncentrowane na pozytywnych aspektach działań). Ostatnia, trzecia, płaszczyzna opisuje to, „w jaki sposób firmy się zachowują." Wyróżnia się tu trzy kwestie: postawę przedsiębiorstwa (postawa otwarta, niepewna i defensywna), spójność działań z wartościami i ze strategią biznesową oraz sposób podejmowania zobowiązań (instrumentalny lub normatywny). Charakter SOP determinowany jest przez sposób w jaki jest ona rozumiana $\mathrm{w}$ danym przedsiębiorstwie. Opisane aspekty i ich wyznaczniki mają natomiast wpływ na tworzenie się szczególnych kategorii poznawczych, które w przedsiębiorstwie kształtują sposób myślenia o społecznej odpowiedzialności, jej postrzeganie, a w konsekwencji sposób, w jaki jest wdrażana w życie ${ }^{7}$.

Relacje pomiędzy organizacjami i ich otoczeniem przedstawione na podstawie powyższych modeli pokazują, że zarówno otoczenie zewnętrzne, jak wewnętrzne, mają wpływ na sposób rozumienia i praktykowania społecznej odpowiedzialności przez podmioty gospodarcze. Za pomocą opisanych modeli można wskazać powiązania między wartościami kultury organizacyjnej a sposobem ich wyrażania w zakresie polityki społecznej odpowiedzialności, jednak nie można stwierdzić, w jakim stopniu przedsiębiorstwo przejmuje swoją odpowiedzialność. Konsekwencją stwierdzenia, że wartości leżące u podstaw systemu mają wpływ na charakter instytucji tworzonych w danym otoczeniu, jest fakt, że w miarę wzrostu wartości odpowiedzialności w danym otoczeniu (zewnętrznym i wewnętrznym), ludzie, przy dokonywaniu indywidualnych wyborów, powinni przywiązywać większą wagę do kwestii odpowiedzialności. $\mathrm{Z}$ drugiej strony, w środowisku, w którym odpowiedzialność nie stanowi wartości, presja wywierana przez społeczeństwo jest stosunkowo niższa, co może prowadzić do usankcjonowania przyzwolenia dla nieodpowiedzialnych i nieetycznych praktyk w życiu gospodarczym. W artykule wartości otoczenia są ujmowane w kontekście indywidualnych wyborów jednostek, dlatego rozpatruje się dwie grupy interesariuszy - pracowników oraz konsumentów. Podobną analizę przeprowadzić można również dla pozostałych grup interesu, jak inwestorzy, dostawcy, klienci instytucjonalni czy społeczności lokalne. Analiza taka musiałaby jednak uwzględniać fakt, że wybory dokonywane przez po-

13 Ibidem, s. 125. 
wyższe grupy $\mathrm{w}$ relacjach $\mathrm{z}$ przedsiębiorstwem nie są lub są bardzo rzadko indywidualnymi wyborami jednostek. Decyzje podejmowane przez podmioty gospodarcze lub grupy społeczne zapadają najczęściej w toku sformalizowanego procesu i w ramach określonych struktur decyzyjnych. $Z$ tego względu artykuł koncentruje się na grupie pracowników oraz klientów indywidualnych - konsumentów, którzy wchodzą $\mathrm{w}$ bezpośrednią relację z przedsiębiorstwem, a których indywidualne wybory przyczyniają się do promowania określonych wartości w życiu społeczno-gospodarczym.

\section{ZACHOWANIA KONSUMENTÓW A SPOŁECZNA ODPOWIEDZIALNOŚĆ PRZEDSIĘBIORSTWA}

Klienci indywidualni zaliczani są do grupy kluczowych interesariuszy przedsiębiorstwa, a ich siła oddziaływania zwiększa się w warunkach rosnącej konkurencji. Konsument jest jednym z głównych decydentów, mających wpływ na decyzje o kierunku rozwoju organizacji. Przedsiębiorcy podkreślają często: „klient jest moim pracodawcą”, co wskazuje na powiązanie decyzji klientów z kierunkiem rozwoju przedsiębiorstwa. Równocześnie, „bycie konsumentem” czy „bycie klientem” jest jedną z głównych ról przypisywanych człowiekowi w społeczeństwach rozwiniętych. Rola ta dominuje ludzkie zachowania i wybory, natomiast system społeczno-gospodarczy determinuje w znaczny sposób wartości, będące podstawą dokonywanych przez jednostki wyborów. W literaturze opisywane są dwa sposoby postrzegania suwerenności wyborów konsumenckich. $Z$ jednej strony wskazuje się, że konsumenci dokonując wyboru w trakcie zakupów, decydują pośrednio, która firma utrzyma się na rynku, a która nie. Przeciwnicy takiego sposobu postrzegania roli konsumenta podkreślają, że konsumenci są poddawani manipulacji za pomocą „sztuczek marketingowych", dzięki czemu przedsiębiorstwa nakłaniają konsumentów do dokonywania wyborów, które często mogą być dla nich niekorzystne ${ }^{8}$.

Dla zrozumienia relacji przedsiębiorstwo-konsument istotne jest rozpatrzenie kwestii niesymetryczności, która odnosi się do równowagi sił oddziaływania obu aktorów. Przedsiębiorstwo dysponuje zasobami wiedzy, posiada informacje o swoich klientach, podejmuje decyzje w ramach działań profesjonalnych, podczas gdy konsument nie ma możliwości dotarcia do informacji na temat faktycznego funkcjonowania i sposobu prowadzenia działań przez wszystkich producentów i usługodawców, z którymi zawiera lub zamierza zawrzeć kontrakt. Pojedynczy klient ma wybór: kupić lub nie kupo-

\footnotetext{
${ }^{14}$ A. Lewicka-Strzałecka, O odpowiedzialności konsumenta, „Prakseologia” 2002, no. 142.
} 
wać, przy czym w skrajnych sytuacjach, np. monopolu, bez względu na preferencje musi przystać na warunki określone przez usługodawcę. $Z$ punktu widzenia realizacji koncepcji SOP kluczową kwestią jest to, że przedsiębiorstwo jest traktowane całościowo. Oznacza to, że nie rozpatruje się jedynie kwestii „społecznie odpowiedzialnych produktów”, ale produktów oferowanych przez firmę społecznie odpowiedzialną. Obok jakości i bezpieczeństwa produktów i usług bierze się pod uwagę również takie kwestie jak sposób ich wytworzenia, przejrzystość komunikacji czy respektowanie praw konsumentów.

Społeczną odpowiedzialność przedsiębiorstwa rozważa się zarówno pod kątem wewnętrznego funkcjonowania organizacji, jak i pod kątem jej wpływu i sposobu budowania relacji $z$ zewnętrznymi grupami interesu, m.in. z klientami. Analizując dążenia i oczekiwania klientów można zidentyfikować pewne obszary, w ramach których przejmowanie przez przedsiębiorstwo dodatkowej odpowiedzialności będzie przez nich cenione. Analiza relacji między organizacją a konsumentem nie może zakończyć się na rozpatrzeniu zagadnień dotyczących odpowiedzialności przedsiębiorstwa, ale musi uwzględnić również zagadnienie odpowiedzialności odbiorcy. Warto w tym miejscu zadać pytanie o to, kim jest, lub powinien być „odpowiedzialny konsument”?

Grupy odbiorców najczęściej charakteryzuje się za pomocą kategorii, tj: wiek, płeć, narodowość, wysokość dochodu, poziom wykształcenia, lub kategorii dotyczących stylu życia czy uznawanych wartości. Czynniki te wydają się jednak niewystarczające dla stworzenia obrazu odpowiedzialnego konsumenta. Obraz taki powinien odzwierciedlać cechy charakterystyczne dla odbiorców przedsiębiorstwa społecznie odpowiedzialnego, czyli tych, dla których społeczna odpowiedzialność stanowi dodaną wartość działalności gospodarczej oraz dodatkowy atrybut produktu lub usługi. Odwołując się do przytoczonej definicji Basu i Palazzo, wartość społecznej odpowiedzialności odnieść można zatem również do sposobu postrzegania przez konsumentów ich roli w procesie tworzenia wspólnego dobra.Lewicka-Strzałecka, nawiązując do refleksji filozoficznej na temat odpowiedzialności wskazuje, że odpowiedzialność konsumenta jest traktowana jako „odpowiedzialność kogoś za coś, wobec jakiejś instancji”, a „zakres tej odpowiedzialności jest wyznaczony przez zakres swobody działania i poczucie sprawstwa”, co oznacza, że człowiekowi powinno się przypisywać odpowiedzialność jedynie za czyny lub ich skutki, których był sprawcą ${ }^{9}$. Autorka uznaje jednak, że najodpowiedniejszym ujęciem dla scharakteryzowania odpowiedzialności konsumenta jest odpowiedzialność pozytywna, która odnosi się do zadań stojących przed człowiekiem, a nie rozpatrywania konsekwencji popełnionych czynów. Jej zdaniem odpowiedzialność po-

15 Ibidem. 
zytywna nadaje życiu człowieka określoną orientację, która wpływa na sposób postrzegania zjawisk oraz pośrednio kształtuje wybory: „konsument jest odpowiedzialny nie tyle za każdy ze swoich pojedynczych czynów - wyborów, choćby ze względu na jego niewielką moc sprawczą, ile za kierunek swoich decyzji rynkowych" ${ }^{10}$. Takie podejście, podobnie jak w przypadku analizy istoty odpowiedzialności konsumenta, naświetla kwestię odpowiedzialności podmiotów gospodarczych w skali makro. Pojedyncza organizacja, podobnie jak i pojedynczy klient, nie ma mocy sprawczej, która spowoduje, że gospodarka światowa zacznie zmierzać w kierunku rozwoju zrównoważonego. Odpowiedzialność o charakterze pozytywnym nie wynika $z$ nakazu prawa czy strachu przed utratą klientów (jest dobrowolna), ale z chęci przejęcia odpowiedzialności za kierunek decyzji rynkowych.

Osobnego rozpatrzenia wymaga natomiast kwestia sposobu podejmowania decyzji przez konsumenta. O ile można przychylić się do stwierdzenia, że przedsiębiorstwa mogą podejmować decyzje $\mathrm{z}$ uwzględnieniem perspektywy długofalowej, to otwarte pozostaje pytanie, czy ten sam mechanizm odnosi się do pojedynczych konsumentów? Czy w chwili zakupu artykułów codziennego użytku, jak żywność, ubrania, kosmetyki, etc. kupujący jest skłonny brać odpowiedzialność za „kierunek swoich decyzji rynkowych”? Wyniki badań wskazują, że nie ma zgody, co do stwierdzenia, że klienci są skłonni zapłacić więcej za produkt „społecznie odpowiedzialny” lub oferowany przez „odpowiedzialne przedsiębiorstwo". Podkreśla się również, że klienci są zainteresowani takimi produktami wówczas, gdy jakość, korzyści i cena są w odpowiednim stosun$\mathrm{ku}^{11}$. Część badań wskazuje, że istotnymi determinantami zakupów „społecznie odpowiedzialnych" są otoczenie i warunki, w których klient dokonuje wyboru. Konsumenci, którzy podejmują decyzję w warunkach przejrzystości oraz ci, którzy są zaangażowani w kwestie środowiskowe i społeczne, w większym stopniu są skłonni wybrać produkt firmy odpowiedzialnej społecznie. Badania wskazują również, że przy dokonywaniu odpowiedzialnych wyborów czynnikami bardziej istotnymi niż wiek czy dochód są indywidualne wartości kupujących $^{12}$. Istnieją jednak również analizy, z których wynika, że nie ma bezpośredniej zależności pomiędzy tym, co konsumenci deklarują w wypowiedziach na temat swoich wyborów, a ich faktycznymi zachowaniami ${ }^{13}$.

${ }^{16}$ Ibidem.

17 Finding The Green in Today's Shoppers, Deloitte Consulting LLP, The Association of Food, Beverage and Consumer Products Categories, 2008, s. 4.

18 J. Cotte, Socially Conscious Consumerism. A systematic Review of the Body of Knowledge, Network for Business Sustainability, 2009, s. 7.

${ }^{1}$ Ibidem, s. 34. 
Przywołane rezultaty badań zdają się potwierdzać tezę o pozytywnym charakterze odpowiedzialności konsumenta, stanowiącej podstawę rozwoju społecznej odpowiedzialności wśród przedsiębiorstw, przy czym kwestią kluczową jest tu spójność wartości. Ustalenie równowagi, opartej na jedności wartości pomiędzy konsumentem i przedsiębiorstwem, skłania do refleksji na temat pożądanych zachowań przedsiębiorstw oraz pożądanej sylwetki odbiorcy. Obszary wyróżnione przez Basu i Palazzo dla celów analizy charakteru społecznej odpowiedzialności (płaszczyzna poznawcza, lingwistyczna oraz płaszczyzna odnosząca się do zachowań przedsiębiorstw) pozwalają na wyodrębnienie punktów istotnych dla usystematyzowania charakterystyki odpowiedzialności konsumentów. Podobnie, jak w przypadku analizy charakteru odpowiedzialności podmiotów gospodarczych, wskazują one na powiązanie między wartościami, które są podstawą tego, w jaki sposób konsumenci postrzegają swoje relacje $z$ przedsiębiorstwami, a rozumieniem i interpretowaniem komunikatów wysyłanych przez przedsiębiorstwo oraz zachowaniami i wyborami dokonywanymi przez klientów. W przedstawionej charakterystyce założono, że wymienione cechy składają się na wyidealizowany model postawy klienta, który stanowi odzwierciedlenie wartości i cech, zawartych w modelu odpowiedzialnego przedsiębiorstwa. Jeżeli od firm oczekujemy przejmowania odpowiedzialności $\mathrm{w}$ obszarze zawierania transakcji, kształtowania relacji z interesariuszami lub dążenia do integracji celów społecznych i ekonomicznych, to konsumenci (jako partnerzy relacji) powinni pożądać i doceniać wartości, tj. dotrzymywanie zobowiązań przez przedsiębiorstwo (nie tylko w kontekście relacji przedsiębiorstwo-odbiorca indywidualny, ale również $\mathrm{w}$ relacjach $\mathrm{z}$ innymi grupami interesu), współpraca i partnerstwo, oraz dążenie do zrównoważonego rozwoju. Odpowiedzialny konsument powinien również wykazywać zainteresowanie działalnością podmiotów gospodarczych w kwestiach środowiskowych i społecznych, mieć wiedzę z tego zakresu oraz chęć jej pogłębiania. Kluczową kwestią jest tu dokonywanie wyborów zgodnych z przekonaniami (wartościami) oraz posiadaną przez konsumenta wiedzą (krytyczna ocena działań, chęć udzielania informacji zwrotnej na temat działań przedsiębiorstw, jak i promowanie dobrych praktyk).

Tabela 1 zawiera modelowe charakterystyki odpowiedzialnego przedsiębiorstwa i odpowiedzialnego konsumenta w odniesieniu do omawianych płaszczyzn. Pokazuje ona wybrane, modelowe cechy i zachowania klientów przedsiębiorstw społecznie odpowiedzialnych. Ważne jest, aby przejmowanie odpowiedzialności przez firmy względem społecznego otoczenia stanowiło istotną wartość dla ich klientów. Promowanie idei społecznej odpowiedzialności powinno być zatem również ukierunkowane na przekazywanie wiedzy oraz wzmacnianie świadomości w obszarze zachowań konsumenckich. 
Tabela 1. Zestawienie postaw w relacji odpowiedzialne przedsiębiorstwo-odpowiedzialny konsument

\begin{tabular}{|c|l|l|}
\hline OBSZAR & \multicolumn{1}{|c|}{ PrzedsıęBIORSTwo } & \multicolumn{1}{|c|}{ KonsumENT } \\
\hline Rozumienie & $\begin{array}{l}\text { Związki z interesariuszami oparte są na: transakcjach, } \\
\text { relacjach, wspólnym celu. } \\
\text { Główne motywy postępowania: przekonanie o użytecz- } \\
\text { ności działań, o zgodności działań lub o ich słuszność. }\end{array}$ & $\begin{array}{l}\text { Wartości: dotrzymywanie zobowiązań i wy- } \\
\text { soka jakość produktów; partnerstwo i po- } \\
\text { szanowanie ludzkiej pracy; zrównoważo- } \\
\text { ny rozwój. }\end{array}$ \\
\hline \multirow{5}{*}{ Komunikacja } & $\begin{array}{l}\text { Argumenty: naukowe, prawne, ekonomiczne, etyczne. } \\
\text { Przekaz: pełny, wybiórczy (wybrane obszary, środki } \\
\text { przekazu, rzetelność informacji). }\end{array}$ & $\begin{array}{l}\text { Wiedza: zainteresowanie (np. procesami } \\
\text { produkcji i wytwarzania produktów), poszu- } \\
\text { kiwanie informacji, znajomość prawa (np. } \\
\text { praw konsumenta), refleksja nad rolą przed- } \\
\text { siębiorstwa w społeczeństwie. }\end{array}$ \\
\hline Działanie & $\begin{array}{l}\text { Obszary realizacji: polityka produktowa, działania wo- } \\
\text { bec pracowników, dostawców, etc. } \\
\text { Sposób realizacji: konkretne programy i narzędzia. } \\
\text { Ciągłość i spójność: zgodność z kulturą organizacyjną } \\
\text { i ze strategią przedsiębiorstwa. }\end{array}$ & $\begin{array}{l}\text { Aktywność: dokonywanie wyborów zgod- } \\
\text { nie z preferowanymi wartościami i moty- } \\
\text { wowanych posiadaną wiedzą, zaangażowa- } \\
\text { nie (udzielanie informacji zwrotnej i aktywne } \\
\text { przeciwstawianie się złym praktykom). }\end{array}$ \\
\hline
\end{tabular}

Źródło: opracowanie własne.

\section{SPOŁECZNA ODPOWIEDZIALNOŚĆ PRZEDSIĘBIORSTW A POSTAWY PRACOWNIKÓW}

Analogiczne rozważania na temat zależności charakteru społecznej odpowiedzialności podmiotów gospodarczych od warunków ich funkcjonowania przeprowadzić można w stosunku do drugiej kluczowej grupy interesu, którą stanowią pracownicy przedsiębiorstwa. W tym przypadku kwestia jest bardziej złożona, ponieważ obie strony łączy umowa, na mocy której jedna strona świadczy usługi (pracę) na rzecz drugiej strony. Relacja przedsiębiorstwo-pracownik jest w dużej części uregulowana prawnie, a większość działań podejmowanych przez firmę na rzecz pracowników będzie miała znamiona dążenia do realizacji konkretnych celów organizacyjnych. Specyficzny charakter relacji powoduje, że kwestie obejmujące społeczną odpowiedzialność są różnie interpretowane - nie jako działania świadczące o dobrowolnym przejmowaniu przez przedsiębiorstwa odpowiedzialności, ale jako standardowe praktyki, obliczone na „przyciągnięcie” i utrzymanie wartościowych pracowników. W literaturze zauważa się, że podczas gdy przedsiębiorstwa europejskie uzasadniają prowadzenie programów, mających na celu pogodzenie życia zawodowego i prywatnego pracowników kwestią społecznej odpowiedzialności, przedsiębiorstwa amerykańskie realizują podobne programy przede wszystkim ze względu na zdobycie przewagi konkurencyjnej ${ }^{14}$.

2 D. Clutterbuck, Równowaga między życiem zawodowym a osobistym, Oficyna Ekonomiczna, Kraków 2005, s. 37. 
Analizując relację pracodawca-pracownik z punktu widzenia teorii interesariuszy należy uwzględnić oczekiwania obu stron oraz prześledzić sposób ich realizacji. Oznacza to, że sylwetka odpowiedzialnego pracodawcy w oczach pracowników odnosić się będzie do stawianych mu wymagań. To, czego pracownicy oczekują od swoich pracodawców zależy od wielu czynników (indywidualnych dążeń, zdolności, sytuacji życiowej, czynników demograficznych itp.), co utrudnia jednoznaczne sprecyzowanie oczekiwań pracobiorców jako grupy. Można jednak podjąć próbę zidentyfikowania obszarów istotnych dla kształtowania tej relacji. Badania US Center for Ethics and Corporate Responsibility wykazują, że najważniejszym problemem etycznym dla przedsiębiorstwa jest „trudność w osiągnięciu (przez pracowników) wysokiej sprawności w pracy przy jednoczesnym silnym zaangażowaniu się w życie rodzinne"15. Liczne sondaże amerykańskie wskazują nawet, że wysoki odsetek pracowników deklaruje gotowość zrezygnowania z części wynagrodzenia w zamian za możliwość poświęcenia większej ilości czasu rodzinie ${ }^{16}$. W Polsce badania na temat czynników, wpływających na postrzeganie pracodawców przez pracowników koncentrują się przede wszystkim na wizerunku pracodawcy oraz czynnikach wzmacniających zaangażowanie uczestników organizacji. Ogólnopolskie badanie „Postawy pracownicze", przeprowadzone przez TNS OBOP (2007) pokazuje, że najważniejszymi elementami pozytywnie kształtującymi wizerunek pracodawcy są odpowiednie warunki zatrudnienia oraz warunki pracy, natomiast na negatywny wizerunek pracodawcy wpływa zły system wynagrodzeń oraz brak możliwości rozwoju i awansów ${ }^{17}$. Podobnie w badaniu przeprowadzonym przez Hewitt Associates pracownicy przedsiębiorstw, które zostały laureatami konkursu „Najlepsi Pracodawcy Roku 2008” podkreślają, że w ich miejscach pracy przykłada się wagę do zbilansowania życia prywatnego i zawodowego ${ }^{18}$. Badania na temat czynników decydujących o atrakcyjności pracodawców prowadzone wśród studentów pokazują, że obok dobrej atmosfery w pracy, możliwości rozwoju oraz wysokiego wynagrodzenia, jako jeden z najistotniejszych czynników wskazywane jest także zapewnienie równowagi między życiem osobistym i zawodowym ${ }^{19}$.

Wydaje się jednak, że identyfikowanie obszarów odpowiedzialności przedsiębiorstwa w obszarze wewnętrznym jedynie poprzez wskazanie oczekiwań

3 Ibidem, s. 41.

${ }^{4}$ Ibidem, s. 38-42.

${ }_{5}$ Postawy Pracownicze Raport, TNS OBOP 2007, s. 3; http://www.nf.pl (data pobrania 10.09.2008)

${ }^{6}$ Badanie Najlepsi Pracodawcy, Hewitt Associates, 2008, s. 11-15; http://www.najlepsipracodawcy.pl (data pobrania 10.02.2009)

7 Raport Pracodawca Roku, Ipsos, AIESEC 2008, s.11; http://www.pracodawcaroku.pl (data pobrania 10.02.2009). 
pracowników nie jest wystarczające. E. Sternberg (2001) wskazuje na trudności z identyfikacją faktycznych oczekiwań grup interesariuszy, oraz na kwestie związane $\mathrm{z}$ rozbieżnością tych oczekiwań: jak określić zakres odpowiedzialności, który pracobiorcy są skłonni przyjąć, jak traktować kwestie dotyczące sposobu i wzrostu wynagrodzenia czy rozpiętości czasu pracy ${ }^{20}$ ? W zależności od warunków otoczenia, jedni pracownicy oczekują skrócenia czasu pracy, natomiast inni - wydłużenia; jedni pragną utrzymania status quo w czasach trudności finansowych, inni są skłonni zgodzić się np. na skrócenie czasu pracy. Ze względu na zmienność i niejednorodność oczekiwań uczestników organizacji, częste są sytuacje, w których przedsiębiorstwo stara się wprowadzać zmiany w systemie zarządzania pod kątem tego, czego w domniemaniu chcą pracownicy, jednak zamiast poprawy efektywności i wzrostu zadowolenia następuje dezintegracja, wzrost niezadowolenia i poczucie niesprawiedliwości ${ }^{21}$. W dyskusji na temat społecznej odpowiedzialności pracodawców, w której uwaga skupia się na zabezpieczeniach socjalnych, a nie kwestiach innowacyjności, czy poprawie efektywności, warto podkreślić, że pracownicy przywiązują dużą wagę do tego, czy przedsiębiorstwo funkcjonuje efektywnie na poziomie biznesowym ${ }^{22}$. Może być to wyrazem chęci posiadania ustabilizowanego pod względem ekonomicznym pracodawcy, co stanowi o bezpieczeństwie zatrudnienia. Pracodawca, który chcąc wzmocnić swoją reputację inwestuje wypracowany zysk jedynie $\mathrm{z}$ myślą o budowaniu odpowiedniego wizerunku społecznego, a zaniedbuje zobowiązania względem pracowników, dostawców czy partnerów biznesowych, nie będzie postrzegany jako pracodawca odpowiedzialny. W dyskusji na temat społecznej odpowiedzialności podmiotów gospodarczych podkreślać należy, że nierentowny zakład pracy, który nie wywiązuje się $\mathrm{z}$ podstawowych zadań, jest nieodpowiedzialny przede wszystkim względem swoich pracowników.

Przedsiębiorstwo powinno uwzględniać oczekiwania członków organizacji, jednak istotę społecznej odpowiedzialności wobec pracobiorców powinno odnosić do szerszych kategorii, obejmujących zarówno kwestie odpowiedniego wynagrodzenia za pracę, zapewniającego utrzymanie, jak i zdrowia pracowników, bezpieczeństwa pracy, szacunku wobec osoby ludzkiej oraz poszanowania indywidualności i przekonań. Jak podkreślają Freeman i Gilbert (1991), w strategii przedsiębiorstwa powinno odzwierciedlać się zrozumienie dla wartości jednostek i wartości pozostałych grup interesu. Postulat ten jednak nie

${ }^{8}$ A. Lewicka-Strzałecka, Odpowiedzialność w życiu gospodarczym, IFiS PAN, Warszawa 2006, s. 24.

${ }^{9}$ D. Clutterbuck, op. cit., s. 42-43.

10 Badanie Najlepsi Pracodawcy..., s. 6. 
oznacza „spełniania życzeń” interesariuszy, a odwołuje się do uwzględnienia poważanych przez nich wartości. Wartości te, zakorzenione na poziomie kultury organizacyjnej, mogą stanowić bazę dla budowania porozumienia i akceptacji kierunku rozwoju przedsiębiorstwa przez pracowników.

Tabela 2 uwidacznia, w sposób analogiczny, w jaki określono charakterystykę odpowiedzialnego konsumenta, modelową sylwetkę pracownika. Pracownik odpowiedzialnego przedsiębiorstwa powinien przywiązywać wagę do uczciwego wypełniania zobowiązań, powinien szanować pracę współpracowników oraz być lojalny wobec pracodawcy. Lojalność ta powinna opierać się na krytycznym osądzie własnej roli zawodowej, a nie na ślepym wypełnianiu poleceń. Odpowiedzialny pracownik powinien również posiadać wiedzę konieczną do podejmowania suwerennych decyzji, przy dokonywaniu wyborów kierować się preferowanymi wartościami oraz wykazywać zaangażowanie i inicjatywę zarówno przy wykonywaniu obowiązków, jak i określaniu kierunku rozwoju organizacji.

Tabela 2. Zestawienie postaw w relacji odpowiedzialne przedsiębiorstwo-odpowiedzialny pracownik

\begin{tabular}{|c|l|l|}
\hline \multicolumn{1}{|c|}{ OBSZAR } & \multicolumn{1}{|c|}{ PRzEDSIĘBIORSTwo } & \multicolumn{1}{|c|}{ PraCownIcy } \\
\hline Rozumienie & $\begin{array}{l}\text { Związki z interesariuszami oparte są na: transak- } \\
\text { cjach, relacjach, wspólnym celu. } \\
\text { Główne motywy działań: przekonanie o użyteczno- } \\
\text { ści działań, o zgodności działań lub o ich słuszności }\end{array}$ & $\begin{array}{l}\text { Wartości: dotrzymywanie zobowiązań, współpra- } \\
\text { ca, lojalność (ale nie ślepa); wysoka jakość pracy, } \\
\text { zaangażowanie, osiąganie celu. }\end{array}$ \\
\hline Komunikacja & $\begin{array}{l}\text { Argumenty: naukowe, prawne, ekonomiczne, } \\
\text { etyczne. } \\
\text { Przekaz: pełny, wybiórczy (wybrane obszary, } \\
\text { środki przekazu, rzetelność informacji). }\end{array}$ & $\begin{array}{l}\text { Wiedza: zainteresowanie (np. procesami w przed- } \\
\text { sębiorstwie i ich doskonaleniem), poszukiwanie } \\
\text { refleksja nad własną rolą w przedsiębiorstwie } \\
\text { oraz rolą przedsiębiorstwa w społeczeństwie. }\end{array}$ \\
\hline Działanie & $\begin{array}{l}\text { Obszary realizacji: polityka produktowa, polityka } \\
\text { wobec pracowników, dostawców. } \\
\text { Sposób realizacji: konkretne narzędzia, programy } \\
\text { i ich przebieg. } \\
\text { Ciągłość i spójność: zgodność z kulturą organiza- } \\
\text { cyjną i ze strategią przedsiębiorstwa. }\end{array}$ & $\begin{array}{l}\text { Aktywność: wybór pracodawcy zgodnie z prefe- } \\
\text { rowanymi wartościami, chęć rozwoju, wykazy- } \\
\text { wanie zaangażowania i własnej inicjatywy (np. } \\
\text { doskonalenie procesów), poczucie odpowiedzial- } \\
\text { ności za swoje działania, za innych, za przedsię- } \\
\text { biorstwo (partycypacja) }\end{array}$ \\
\hline
\end{tabular}

Źródło: opracowanie własne.

Analiza relacji pracowników i pracodawców pod kątem społecznej odpowiedzialności wymaga zastanowienia się nad charakterem odpowiedzialności ze strony pracownika. Regulacje prawne określają odpowiedzialność pracownika w ramach jego stosunku pracy, wypełniania obowiązków, zakazu konkurencji, zobowiązań materialnych i finansowych czy działania na szkodę pracodawcy, co wskazuje przede wszystkim na negatywne ujęcie jego odpowiedzialności wobec pracodawcy. Czy można jednak scharakteryzować odpo- 
wiedzialność pracowników także w kategoriach odpowiedzialności pozytywnej? Badanie przeprowadzone przez TNS OBOP (2007) wskazuje, że cechami najbardziej cenionymi u pracowników są przede wszystkim odpowiedzialność oraz dotrzymywanie zobowiązań ${ }^{23}$. Wyniki te pokazują, że dla pracodawców istotniejsze od kreatywności lub innowacyjności jest to, aby pracownik myślał o konsekwencjach swoich poczynań i uwzględniał w swoich decyzjach ewentualne ich skutki. Wyniki te można zinterpretować na kilka sposobów: pracodawcy chcą, żeby pracownicy czuli się odpowiedzialni za swoje działania wynikające ze stosunku pracy, za właściwe funkcjonowanie organizacji lub mieli poczucie współodpowiedzialności za kierunek rozwoju przedsiębiorstwa. Nie wszyscy pracodawcy rozumieją odpowiedzialność pracowników w taki sposób, jednak, zawężając rozważania do tych, którzy są gotowi wprowadzać zasady społecznej odpowiedzialności do codzienności organizacyjnej, zasadne wydaje się twierdzenie, że będą oni chcieli realizować tę koncepcję przy pełnym uczestnictwie swoich pracowników. Podkreślenie przez pracodawców kwestii odpowiedzialności może wskazywać, że nie zawsze widzą oni chęć przejmowania odpowiedzialności przez członków swoich organizacji. W przedsiębiorstwie istotne jest zatem budowanie kultury organizacyjnej, opartej na poczuciu odpowiedzialności nie tylko za siebie i najbliższych, ale - w ramach kontraktu zawartego z pracodawcą - również za kolegów z pracy i za kierunek rozwoju przedsiębiorstwa. Wymienione elementy - w analogii do rozważań na temat odpowiedzialności konsumentów - odnieść można do pozytywnego charakteru odpowiedzialności pracowników, nie „odpowiedzialności za skutki” lecz „odpowiedzialności, za zadania stojące przed człowiekiem” i „odpowiedzialności, która nadaje życiu określoną orientację" ${ }^{24}$. Odwołując się do powyższej analogii zaznaczyć należy, że kluczową rolę odgrywa tu wiedza (znajomość praw i obowiązków pracowniczych, zainteresowanie kwestiami etycznymi i kwestiami odpowiedzialności przedsiębiorstwa) oraz zaangażowanie (podejmowanie działań prewencyjnych w kwestii nieuczciwych lub nieudolnych praktyk, komunikowanie problemów, wykazywanie inicjatywy).

\section{ZAKOŃCZENIE}

Analiza cech odpowiedzialnych postaw konsumenta ukazuje wage odpowiedzialności klienta za jego wybory, zgodne $\mathrm{z}$ indywidualnymi wartościami, np. ochrony własnego zdrowia, zdrowia rodziny oraz za konsekwencje tych wybo-

23 Postawy pracownicze..., s. 3.

24 A. Lewicka-Strzałecka, O odporwiedzialności... 
rów dla innych. Konsumenci powinni przejmować odpowiedzialność za swój wybór, podobnie jak pracownicy powinni zdawać sobie sprawę z konsekwencji swoich dążeń i decyzji. Rozważania na temat realizacji idei społecznej odpowiedzialności wskazują na konieczność uwzględnienia sposobu postępowania pracodawców, ale również postaw pracowników. Jeżeli ze względu na brak równowagi $\mathrm{w}$ posiadanych przez strony zasobach, nie można postulować o partnerski charakter omawianych relacji, to powinny się one opierać na świadomości praw i obowiązków obu stron, konsekwencji działań, długofalowym kształtowaniu relacji przy uwzględnieniu wspólnych wartości, które mogą stanowić podstawę dla realizacji założonych celów.

\section{BIBLIOGRAFIA}

Badanie Najlepsi Pracodawcy, Hewitt Associates, 2008, raport dostępny na stronie: http://www.najlepsipracodawcy.pl (data pobrania: 10.02.2009).

Basu K., Palazzo G., Corporate Social Responsibility: a process model of sensemaking, „Academy of Management Review”, 2008, vol. 33, no. 1.

Clutterbuck D., Równowaga między życiem zawodowym a osobistym, Oficyna Ekonomiczna, Kraków 2005.

Cotte J., Socially Conscious Consumerism. A systematic Review of the Body of Knowledge, Network for Business Sustainability, 2009, artykuł dostępny na stronie: http:// www.nbs.net/Docs/NBS_Consumerism_2009.pdf (data pobrania 10.10.2009).

DiMaggio P. J., Powell W.W., The iron cage revisited: Institutional isomorphism and collective rationality in organizational fields, „American Sociological Review”, 1983, vol. 48.

Finding The Green in Today's Shoppers, Deloitte Consulting LLP, The Association of Food, Beverage and Consumer Products Categories, 2008.

Freeman R. E., Gilbert D. R., Jr, Unternehmensstrategie, Etbik und persönliche Verantwortung, Campus Verlag Frankfurt-New York 1991.

Lewicka-Strzałecka A., Odpowiedzialność w życiu gospodarczym, IFiS PAN, Warszawa 2006.

Lewicka-Strzałecka A., O odpowiedzialności konsumenta, „Prakseologia” 2002, nr 142.

Matten D., Moon J., "Implicit" and "Explicit" CSR: a conceptual framework for a comparative understanding of Corporate Social Responsibility, „Academy of Management Review", 2008, vol. 33, no. 2.

Postawy Pracownicze Raport, TNS OBOP, 2007, raport dostępny na stronie: http://www.nf.pl, (z dnia: 10.09.2008).

Raport Pracodawca Roku, Ipsos, AIESEC, 2008, raport dostępny na stronie: http://www.pracodawcaroku.pl (data pobrania: 10.02.2009).

Scott R. W., Institions and Organization, Thousand Oaks, Sage 2001.

Sternberg E., The Dangers of the Stakeholder Theory, „Prakseologia” 2001, no. 141. 


\title{
ODPOWIEDZIALNE PRZEDSIĘBIORSTWO W ODPOWIEDZIALNYM OTOCZENIU
}

\author{
STRESZCZENIE
}

Koncepcja społecznej odpowiedzialności przedsiębiorstw bazuje na przekonaniu o zgodności interesów społecznych z biznesowymi. Powstaje jednak pytanie, czy odpowiedzialne organizacje mogą funkcjonować $\mathrm{w}$ środowisku, w którym odpowiedzialność nie stanowi wartości?

Niniejszy artykuł koncentruje się na relacjach przedsiębiorstwa $z$ wybranymi grupami interesariuszy: pracownikami oraz indywidualnymi odbiorcami. Omawia się wpływ zachowań konsumentów - ich oczekiwań i wyborów - na działania przedsiębiorstw oraz kwestie dotyczące postaw i odpowiedzialności pracowników względem organizacji.

\section{RESPONSIBLE COMPANY IN RESPONSIBLE SURROUNDING}

\author{
SUMMARY
}

The concept of the Corporate Social Responsibility includes long-time view and it is based on the belief that the social and economic interest could be combined. However, the question is, how should the socially-responsible company behave in the situation where the occasional external expectations it is supposed to meet do not harmonize with the long term goals of the company? One can also ask if a responsible company could have a chance to exist in a irresponsible surrounding?

This article contains some reflection on the character of a company environment and its influence on the corporate responsibility. In particular, it discusses the role and influence of the expectations and behaviors of the consumers and the employees on the corporate social responsibility. 
